Jurnal Konstruksi Hukum | ISSN: 2746-5055

Vol. 2, No. 2, Mei 2021, Hal. 238-243| Tersedia online di

https://www.ejournal.warmadewa.ac.id/index.php/jukonhum

DOI: https://doi.org/10.22225/jkh.2.2.3213.238-243

\title{
PERLINDUNGAN HUKUM TERHADAP ANAK KORBAN TINDAK PIDANA PENCABULAN DILINGKUNGAN KELUARGA
}

\author{
I Gede Susila Putra, Anak Agung Sagung Laksmi Dewi, Ni Made Sukaryati Karma \\ Fakultas Hukum, Universitas Warmadewa, Denpasar - Bali, Indonesia \\ susilaputra98@gmail.com, laksmiidewi29@gmail.com, sukariati64@gmail.com
}

\begin{abstract}
Abstrak
Pencabulan anak-anak ialah permasalahan kemasyarakatan yang bisa membuat keributan dipublik. Pencabulan terhadap anak perlu mendapatkan perhatian serius dari semua kalangan. Menjatuhkan sanksi pidana kepada pelaku tindak pidana pencabulan tentu tidak lepas dari peranan Hakim, Jaksa, dan pihak kepolisian sebagai aparat penegak hukum guna mencapai ketentraman hidup masyarakat. teknik pengumpulan bahan hukum yang digunakan dalam penelitian ini adalah dengan cara pencatatan dalam dokumentasi. Analisis bahan hukum dengan menggunakan metode pengolahan bahan baku secara sistematis, yaitu dengan argumentasi hukum berda arkan logika deduktif dan induktif. Observasi berikut Memanfaatkan metode normatif disebabkan tengah terdapat aruran yang kabur, dan berawal kepada pemikiran para sarjana hukum dan Undang-Undang. Menurut Purusan omor 978/Pid.Sus/2016/PN Dps, hukuman bagi para pelaku pencabulan terhadap anak diarur dalam Pasal 760 jo Pasal 81 Ayat 3 Undang-Undang Nomor 35 Tahun 2014 Tentang Perubahan Atas Undang-Undang Nomor 23 Tahun 2002 Tentang Perlindungan Anak yang berbunyi "Telah melakukan kekerasan atau ancaman kekerasan, mernaksa Anak melakukan persetubuhan dengannya atau dengan orang Jain, yang dilakukan oleh Orang Tua, Wali, pengasuh Anak, pendidik, atau tenaga kependidikan yakni dengan ancaman pidana penjara JO ( sepuluh ) tahun dan denda sebesar Rp. 100.000.000 (seratus juta rupiah). Tujuan dari penelitian ini adalah untuk pemeliharaan hukum kepada kanak korban asusila dan untuk mengetahui hukuman terhadap pelaku perbuatan asusila kepada kanak.
\end{abstract}

Kata Kunci: Perlindungan Hukum, Pencabulan, Anak

\begin{abstract}
Child sexual immorality is a societal problem that can create a commotion in the public. Fornication of children needs serious attention from all circles. Imposing criminal sanctions on perpetrators of criminal acts of sexual immorality certainly cannot be separated from the role of judges, prosecutors, and the police as law enforcement officers in order to achieve peace in people's lives. The technique of collecting legal materials used in this research is by recording it in documentation. Analysis of legal materials using the method of processing raw materials systematically, namely with legal arguments based on deductive and inductive logic. The following observations make use of the normative method because there are vague guidelines, and originate in the thinking of law and law scholars. According to Purusan No. 978 / Pid.Sus / 2016 / PN Dps, punishment for perpetrators of child molestation is stipulated in Article 760 in conjunction with Article 81 Paragraph 3 of Law Number 35 Year 2014 Concerning Amendments to Law Number 23 Year 2002 Concerning Child Protection which reads, "Having committed violence or threats of violence, forcing the child to have intercourse with him or with a Jain, which is carried out by parents, guardians, child caregivers, educators, or education personnel, namely with the threat of imprisonment for 10 (ten) years and a fine of Rp. 100,000,000 (one hundred million rupiah)". The purpose of this study is to maintain the law for child victims of immorality and to determine the punishment for perpetrators of immoral acts to children.
\end{abstract}

Keywords: Legal Protection, Fornication, Children

\section{PENDAHULUAN}

Indonesia adalah daerah yang berlandaskan aturan hukum, oleh sebab itu semua aktivitas yang dilakukan oleh khalayak atau penduduk yang dimana ialah kegiatan hidupnya berlandaskan kebijakan kepada yang telah tersedia serta aruran- aturan yang berlangsung di tengah khalayak. Kriminalitas makin meluas lewat berbagai gaya yang berlainan sampai-sarnpai bersama alat yang kian kompleks serta maju mengakibatkan kriminalitas kian makin menggelisahkan penduduk. KriminaJitas bisa 
muncuJ di manapun dan kapanpun. Bisa didefinisikan bahwasannya kriminalitas berlangsung dalam tiap kehidupan di masyarakat, sehingga terjadilah kejahatan yang bisa melebihi batasan kehidupan contohnya ialah kriminalitas seksual maupun perbuatan kotor.

Pengertian perlindungan adalah tempat berlindung, hal (perbuatan dan sebagainya) melindungi dalam UndangUndang No. 23 Tahun 2002 adalah segala upaya yang ditujukan untuk memberi rasa aman kepada korban yang dilakukan oleh pihak keluarga, advokat, lembaga sosial, kepolisian, kejaksaan, pengadilan, atau pihak lainnya sementara maupun berdasarkan penetapan pengadilan (ELSAM,2015). Menurut Poerwadarminta (1959: 224) pengertian perlindungan hukum adalah tindakan melindungi atau memberi pertolongan dalam bidang hukum. Yang dimaksud perlindungan hukum adalah cara, proses, dan perbuatan melindungi. Menurut Abdul Hakim (1986: 35) mengatakan bahwa : Masalah perlindungan hukum bagi anak-anak merupakan satu sisi pendekatan untuk melindungi anak-anak Indonesia. Masalahnya tidak semata-mata bisa didekati secara yuridis, tapi perlu pendekatan lebih luas,yaitu ekonomi, sosial, dan budaya. Gosita (2004:222) yang dimaksud korban adalah mereka yang menderita jasmaniah dan rohaniah sebagai akibat tindakan orang lain yang mencari pemenuhan kepentingan diri sendiri atau orang lauuin yang berhubungan dengan kepentingan dan hak asasi manusia.

Ada beberapa faktor penyebab yang paling mempengaruhi timbulnya kejahatan anak, yaitu: (Meliala dan Sumaryono: 1985: 31)

1) Faktor lingkungan

2) Faktor ekonomi / sosial

3) Faktor psikologis

Pencabulan ialah satu perbuatan krirninalitas yang kian tidak berkeprimanusian, akhlak, ternoda bahkan melawan peraturan dimana yang merupakan sasaran ialah gadis baik yang berumur ataupun yang masih kanak-kanak yang belum cukup usia. Pencabulan termasuk dalam penggolongan bentuk delik perbuatan asusila berikut bahwasannya telah tertuang di dalam KUHP pada BAB 14 Buku ke- 2 yakni dalam pasal 289 KUHP menyebutkan bahwasannya: Barang siapa dengan kekerasan atau ancaman kekerasan memaksa seseorang untuk melakukan atau membiarkan dilakukan perbuatan cabul, diancam karena melakukan perbuatan yang menyerang kehormatan kesusilaan, dengan penjara paling lama sembilan tahun".

Adapun sebagian golongan sebutan berkaitan perbuatan asusila, ialah :

a. Exhibilitionism: berencana memperlihatkan kemaluan terhadap khalayak umum

b. Voyeurism: mencumbu individu menggunakan hasrat yang tinggi

c. Caress: mengusap alat kemaluan khalayak dengan berencana

d. Fell at: mengharuskan khalayak berikut perlu melaksanakan hubungan bercumbu (Marpaung, 2004:64)

Menurut Bemmellen, kegiatan cabul bahkan arestasi terhadap eksekutor adalah dirudingkan guna menjaga penyelewengan koneksi tertenru, ataupun otoritas tertenru, contohnya ibu dan bapak kandung, ibu dan bapak tiri, wakil, atasan serta penduduk yang sebagai pembimbing, pengajar, ataupun pengawas kanak-kanak yang belum cukup usia yang berkeyakinan bahkan sebagai kewajibannya (Djubaidah dalam Bemmellen, 2010:75).

Menurut Undang-Undang Nomor 23 Tahun 2002 Tentang Perubahan Atas Undang-Undang Nomor 35 Tahun 2014 Tentang Perlindungan Anak Pasal 288, yang berhak berkewajiban melaksnakan pengawasan kepada kanak-kanak yaitu negara, penguasa, sesepuh, kerabat, bahkan penduduk disekelilingnyalah yang mempunyai tanggung jawab bahkan berkewajiban kepada pengawasan kanak- kanak. Sesuai kerentuan Peraturan Pemerintah Pengganti Undang-Undang (Perppu) Nomor I Tahun 2016 tentang Perlindungan Anak. Perlindungan hukum diberikan kepada anak rnerupakan suatu perlindungan yang diberikan oleh Negara atau pemerintah.

Adapun cara yang sudah dilaksanakan oleh pemerintah ditengah melaksanakan suatu tanggung jawab berikut contohnya dengan dibentuknya suatu lembaga Komisi perlindungan Anak Indonesia. Perbuatan asusila yang dilakukan kepada anak-kana kerap terjadi dimana saja terutama yang menjadi pelaku pencabulan adalah ayah kandung sendiri maupun ayah sambung dari anak tersebut, kasus ini terjadi di Jalan Sedap Malam Gg. I No. 5 Kodya Denpasar bermula saat anak 
perempuan dari tersangka Eko Purwanto sedang tengah menonton TV di rumah saat rumah dalam keadaan sepi disana sang ayah ( Eko Purwanto) mencabuli anak kandungnya sendiri, terdakwa mempertanggungjawabkan perbuatannya di persidangan Pengadilan Negeri Denpasar pada tanggal 14 Februari 2017.

Berlandaskan penjabaran latar belakang diatas dapat disumpulkan tujuan dari penelitian ini untuk mengetahui perlindungan hukum terhadap anak korban pencabulan dan sanksi pidana terhadap pelaku pencabulan terhadap anak.

\section{METODE PENELITIAN}

Tipe penelitian yang digunakan dalam penulisan skripsi ini adalah tipe penelitian hukum normatif. Penelitian hukum normatif yaitu merupakan penelitian hukum yang mengkaji hukum tertulis dari berbagai aspek, tetapi tidak mengkaji aspek terapan atau implementasinya (Fathoni, 2016: I 05). Dalam penelitian ini penulis menggunakan pendekatan masalah yang digunakan adalah pendekatan perundang-undangan dan pendekatan konseptual. Sumber bahan hukum yang akan digunakan dalam penelitian ini terdiri atas dua kategori, yaitu bahan hukum primer dan bahan hukum sekunder. teknik pengumpulan bahan hukum yang digunakan dalam penelitian ini adalah dengan cara pencatatan dalam dokumentasi. Analisis bahan hukum dengan menggunakan metode pengolahan bahan baku secara sistematis, yaitu dengan argumentasi hukum berda arkan logika deduktif dan induktif.

\section{HASIL DAN PEMBAHASAN}

\section{Perlindungan Hukum Terhadap Anak Korban Pencabulan di Lingkungan Keluarga}

Pencabulan ialah satu perbuatan yang rnenentang peraturan tentang tata krama serta moral. Hal ini secara tegas diundang-undangkan dalam KUHP, yang berbunyi : Pencabulan merupakan segala tindak kesusilaan yang termasuk kedalam perbuatan keji, dalam hal yang menyangkut nafsu birahi. supaya bisa dikatakan khalayak berikut melakukan perbuatan asusila yang melanggar ketentuan peraturan perundang-undangan Pasal 289, 290, 292, 293, 294, 295, 296 Kitab Undang-Undang Hukum Pidana (KUHP) maka harus memenuhi unsur-unsur:

a. Pasal 289 Kitab Undang-Undang Hukum Pidana, unsur obyektif: Perbuatan: mengharuskan, modusnya : kekejaman, intimidasi tekanan. Obyeknya: khalayak melaksanakan serta membolehkan suatu perbuatan cabul. (Adami Chazawi, 2002:78)

b. Pasal 290 KUHP, ada tiga bentuk kejahatan yang dirumuskan yaitu :

1. Kekejaman nomor I, unit objektifnya :Perbuatannya: perbuatan cabul. Objeknya: dengan seseorang.Dalam keadaan, pingsan, tidak berdaya.

2. Kekejaman nomor 2, unsur objektifnya : Perbuatannya: perbuatan cabul. Objeknya: bersama khalayak yang dimana usianya tidak sampai 15 tahun, atau bahkan apabila belum transparan usianya khalayak tersebut tidak waktunya untuk melaksanakan pernikahan.

3. Kekejaman nomor 3, unit obyektifnya: dengan cara: mempengaruhi. Obyeknya: khalayak lain usianya tidak sampai lima betas umurnya serta apabila usianya belum transparan serta tidak waktunya untuk melaksanakan perkawinan. Unsur Subjektifnya: usianya tidak sampai 15 tahun, atau bahkan apabila belum transparan usianya yang berhubungan tidak waktunya untuk melaksanakan pernikahan.

c. Pasal 292 KUHP, Unsur objektif: Perbuatannya : perbuatan cabul yang si pembuatnya adalah oleh orang dewasa. Objeknya adalah pada sesama jenis kelamin yang belum dewasa.

d. Pasal 293 KUHP, Unsur objektif: Perbuatan: menjalankan ialah tingkah laku yang rnerajai kemauan khalayak lain, ataupun memasukkan dampak daripada keinginan khalayak lain menuju kemauannya sendiri, ataupun supaya sama dengan keinginannya sendiri. Objeknya yaitu orang yang belum dewasa maksudnya orang yang belum genap 21 tahun umumya dan belum menikah.

e. Pasal 294 KUHP, Unsur objektif: Perbuatannya adalah perbuatan cabul. Objek adalah kepada kanak-kanak yang tidak berumur, kepada anak angkarnya yang tidak berumur, kepada kanakkanak yang dibawah tanggung jawab yang tidak berumur, asisten rumah tangga yang tidak berumur. 
f. Pasal 295 Kitab Undang-Undang Hukum Pidana (KUHP), ada tiga bentuk kejahatan yang dirumuskan yaitu :

1. Butir 1 ,

Unsur objektifnya: kegiatannya mengakibatkan aktivitas cabul, melancarkan kegiatan cabul. Objeknya oleh kanak-kanak yang tidak cukup umur, anak tirinya yang tidak cukup umur, anak angkatnya yang tidak cukup umur, anak dibawah tanggungjawab yang tidak cukup umur kepada khalayak yang membimbingnya pendidikan ataupun pembantunya diberikan terhadap yang tidak cukup umur. Unsur subjektif: karena terencana

2. Butir 2, objektifnya: Perbuatannya: mengakibatkan kegiatan asusila, Objeknya: memuluskan kegiatan asusila yang dilakukan kepada khalayak yang tidak cukup umur Unsur Subjektifnya: Dengan sengaja

g. Pasal 296 KUHP Unsur objektif:

Perbuatannya: mengakibatkan terjadinya kegiatan asusila, melancarkan kegiatan asusila. Objek: terhadap orang lain bersama orang lain dengan sengaja.

Menurut Muchsin bentuk perlindungan hukum dapat dibedakan menjadi 2 (dua) yairu:

1. Perlindungan Hukum Preventif: pemeliharaan yang dimana diperoleh dari pemerintah dengan bermaksud guna menekankan dini berlangsungnya suaru pelanggaran. Hal berikut ditemukan di dalam ketentuan norma ketetapan dengan bertujuan guna menahan satu kesalahan bahkan mempersembahkan batasan-batasan ditengah melaksanakan suatu tanggung jawab.

2. Perlindungan Hukum Represif : pemeliharaan paling akhir yaitu dengan bersifat hukuman contohnya ganti rugi, kurungan, ataupun sanksi tambahan yang diperoleh jika telah mengakibatkan suaru konflik atau bahkan sudah diperbuatnya saru pengingkaran. pernecahan banruan hukum unruk Majelis Hukum Umum serta Majelis Hukum Administrasi di Indonesia tergolong bagian pengawasan hukum berikut. (Muchsin Alatas, 2011 :93) Dalam ketentuan peratuuram perundang-undangan Pasal I ayat 2 UU No.35/2014 Tentang Perubahan Atas UU No. 23/2002 Tentang Perlindungan Anak, yang berkewajiban melaksanakan pengawasan kepada kanak-kanak ialah negara, penguasa, sesepuh, famili, bahkan penduduk disekelilingnyalah yang mempunyai peran bertanggung jawab dan bertujuan kepada pengawasan kanak-kanak. Adapun cara yang sudah dilaksanakan oleh pemerintah di tengah melaksanakan suaru tanggung jawab berikut contohnya dengan dibenruknya suatu lembaga Komisi perl indungan Anak Indonesia.2. Sanksi Pidana Bagi Pelaku Perbuat An Cabul Terhadap Anak Di Ling Kung An Keluarga. Hukuman suatu tindakan kriminal ialah satu ganjaran kausalitas, asal mula ialah perkaranya serta dampaknya ialah ganjarannya, individu yang tertimpa darnpaknya akan menerima ganjaran baik masuk jeruji besi maupun tertimpa ganjaran yang lainnya oleh pihak kepol isian. Sanksi pidana adalah dalam arurannya adalah suatu penanggung guna mengembalikkan tingkah laku oleh eksekutor kriminalitas berikut, akan tetapi tidak jarang bahwasannya sanksi pidana dilahirkan demi satu intimidasi oleh keahlian khalayak itu sendiri (Andrisman, 2009:8).

Jenis-jenis sanksi pidana sebagaimana telah diatur dalam ketentuan Pasal 10 Kitab UndangUndang Hukum Pidana (KUHP) :

1. Pidana Pokok:

a. Pidana mati : pidana yang terberat dibandingkan dengan jenis pidana lainnya. Tindak hukuman mati belum secara gampang diimplementasikan. menerapkan kebijakan hukuman mati acap kali diintimidasi pula prefensinya, ialah hukuman kurungan seumur hidup ataupun bahkan hukuman kurungan paling optimal dua puluh tahun.

b. Pidana penjara: bentuk hukuman yang dirnana berjeniskan ketiadaannya satu kemerdekaan yang diperoleh. terdapat masa kepada hukuman kurungan berikut dalam Pasal 12 KUHP

c. Pidana Kurungan : diatur dalam Pasal 18 KUHP. Sama definisinya dengan pidana penjara,

d. Pidana denda : diancam kan dan sering sebagai alternatif dari pidana kurungan terhadap hampir semua pelanggaran yang tercantum dalam buku III KUHP. 
e. Pidana tutupan: Pada Pasal 10 KUHP dicantumkan pidana tertutup sebagai pidana pokok bagian terakhir di bawah pidana denda.

2. Pidana Tambahan :

a. Pidana penghapusan kedaulatan khusus : penghapusan bisa diberlakukan kepada keseluruhan kewenangan. Hal ini dikarenakan dengan ditariknya keseluruhan kewenangan, oleh sebab itu bertolak belakang dengan ketentuan Pasal 3 KUHPerdata

b. Pidana perampasan barang-barang tertenru : ialah suatu hukuman tambahan yang kerap kali diberikan daripada hukuman tambahan yang lainnya. Pidana perampasan barang-barang tertentu sendiri tertuang secara detail pada Pasal 39 KUHP.

c. Pidana pemberitahuan pertimbangan ketua pengadilan : pemberitahuan pertimbangan kerua pengadilan diburuhkan pengumuman tambahan. Ketua pengadilan leluasa guna memilih lokasi siaran, ialah baik di koran, dibikin poster yang direkatkan di dinding gedung instirusi negara, atau yang lainnya yang tentunya bisa diakses terhadap khalayak awam, pemberitahuan dengan iklan melalui radio, dan seterusnya.

Perbuatan asusila berkaitan dalam penggolongan bentuk delik perbuatan asusila berikut bahwasannya telah tertuang didalam KUHP pada BAB 14 Buku ke- 2 yakni dalam pasal 289 KUHP bahwasannya "Barang siapa dengan kekerasan atau ancaman kekerasan memaksa seseorang untuk melakukan atau membiarkan dilakukan perbuatan cabul, diancam karena melakukan perbuatan yang menyerang kehormatan kesusilaan, dengan penjara paling lama sembilan tahun". Kekejaman seksual kepada gadis apalagi terhadap buah hati sendiri waktu ini makin bertambah. Hal ini dikarenakan KUHP dan UU dianggap kurang efektif, maka dari itu pemerintah mengesahkan peraturan pemerintah pengganti VU No. 1/2016 menjadi UU No. 17/2016 dimana mengaplikasikan pernberatan sanksi terhadap pelaku kriminalitas kekejaman sensual contohnya ialah dengan mempergunakan hukuman kebiri dengan kimiawi.

\section{IV.SIMPULAN DAN SARAN}

\section{Simpulan}

Perlindungan hukum terhadap anak korban pencabulan diberikan kepada anak ke dalam bentuk yang bersifat preventif maupun yang bersifat represif, baik yang I isan maupun yang tertulis, Bisa diartikan bahwasannya pengawasan hukum menjadi satu permasalahan menyendiri baik rujuan hukum itu sendiri maupun yang rnempunyai rencana bahwasannya hukum rnenganjurkan suaru kesamarataan, keteraruran, ketegasan, kemanfaatan. Pencabulan diatur dalam Pasal 289 sampai dengan Pasal $296 \mathrm{Ki}$ tab Undang• Undang Hukum Pidana (KUHP) BAB XIV Buku ke-11. Pencabulan digolongkan kedalam jenis tindak pidana kesusilaan. Hukuman terhadap pemeran perbuatan asusila kepada kanakkanak tertuang dalam Pasal 760 jo Pasal 81 Ayat 3 Undang-Undang Nomor 35 Tahun 2014 Tentang Perubahan Atas Undang-Undang Nomor 23 Tahun 2002 Tentang Perlindungan Anak dapat diancam pidana penjara sepuluh tahun dan denda sebesar seratus juta rupiah.

\section{Saran}

Berdasarkan simpulan tersebut diatas, dapat dikemukakan saran kepada para pihak terkait, sebagai berikut :

1. Bagi Pemerintah ditengah hal berikut selaku aparat yang mempunyai kekuasaan, seharusnya mempelajari kembali Undang-Undang tentang Perlindungan Anak terpaut hukuman kepada pelaku asusila, supaya hat berikut tidak terjadi lagi supaya bisa memperoleh efek taubat terhadap pelaku perbuatan asusila.

2. untuk kepada Pemangku kebijakan hukum salah satunya di antaranya polisi,jaksa atau bahkan ketua pengadilan guna menghadiahi satu hukuman nan setimpal selaras bersama peraturan UndangUndang terhadap aktor perbuatan asusila kepada kanak-kanak supaya tidak ada lagi kanak-kanak yang sebagai target kriminalitas seksual terutama perbuatan asusila terhadap kanak-kanak. 


\section{DAFTAR PUSTAKA}

Andrisman, T. (2009). Asas-Asas dan Dasar Aturan Hukum Pidana Indonesia. Penerbit Universitas Lampung, Lampung.

Djubaedah, N. (2010). Perzinaan dalam peraturan perundang-undangan di Indonesia ditinjau dari hukum islam. Kencana Prenada Group, Jakarta.

ELSAM. (2015). UU Nomor 23 Tahun 2002 tentang Perlindungan Anak. Referensi HAM.

Fathoni, A. (2006). Metodologi Penelitian dan Teknik Penyusunan Skripsi. PT Rineka Cipta, Jakarta.

Gosita, A. (2004). Masalah Perlindungan Anak. Akademi Pressindo, Jakarta.

Hakim, A. (1986). Hukum dan Hak-hak Anak. Garuda Nusantara, Jakarta.

Marpaung, L. (2004). Kejahatan terhadap kesusilaan dan masalah prevensinya. Sinar Grafika.

Meliala, A. S. dan E. S. (1985). Kejahatan anak suatu tinjauan dari psikologi dan hukum. Liberty, Yogyakarta.

Muchsin Alatas, 2011, Perlindungan Hukum di Indonesia, Bumi Mas, Depok

Poerwadarminta, W. J. S. (1986). Kamus Umum Bahasa Indonesia. Balai Pustaka, Jakarta. 